\title{
The Role of a New Compound Micronutrient Multifunctional Fertilizer against Verticillium dahliae on Cotton
}

\author{
Yalin Zhang ${ }^{1}$, Lihong Zhao ${ }^{1}$, Zili Feng ${ }^{1}$, Hongfu Guo ${ }^{2}$, Hongjie Feng ${ }^{1,3}$, Yuan Yuan ${ }^{1}$, Feng Wei ${ }^{1,3, *}$ \\ and Heqin Zhu 1,3,* \\ 1 State Key Laboratory of Cotton Biology, Institute of Cotton Research, Chinese Academy of Agricultural \\ Sciences, Anyang 455000, China; zhangyalin@caas.cn (Y.Z.); zhaolihong@caas.cn (L.Z.); \\ fengzili@caas.cn (Z.F.); fenghongiie@caas.cn (H.F.); yuanyuan06@caas.cn (Y.Y.) \\ 2 Puyang City Academy of Agricultural Sciences, Puyang 457000, China; guohongfu@caas.cn \\ 3 State Key Laboratory of Cotton Biology, Zhengzhou Research Base, Zhengzhou University, \\ Zhengzhou 450000, China \\ * Correspondence: weifeng@caas.cn (F.W.); zhuheqin@caas.cn (H.Z.)
}

Citation: Zhang, Y.; Zhao, L.;

Feng, Z.; Guo, H.; Feng, H.; Yuan, Y.; Wei, F.; Zhu, H. The Role of a New Compound Micronutrient Multifunctional Fertilizer against Verticillium dahliae on Cotton.

\section{Pathogens 2021, 10, 81.}

https://doi.org/10.3390/ pathogens 10010081

Received: 16 December 2020

Accepted: 15 January 2021

Published: 19 January 2021

Publisher's Note: MDPI stays neutral with regard to jurisdictional claims in published maps and institutional affiliations.

Copyright: (c) 2021 by the authors. Licensee MDPI, Basel, Switzerland. This article is an open access article distributed under the terms and conditions of the Creative Commons Attribution (CC BY) license (https:// creativecommons.org/licenses/by/ $4.0 /)$.

\begin{abstract}
Verticillium dahliae Kleb., the causal pathogen of vascular wilt, can seriously reduce the yield and quality of many crops, including cotton (Gossypium hirsutum). To control the harm caused by $V$. dahliae, considering the environmental pollution of chemical fungicides and their residues, the strategy of plant nutrition regulation is becoming increasingly important as an eco-friendly method for disease control. A new compound micronutrient fertilizer (CMF) found in our previous study could reduce the damage of cotton Verticillium wilt and increase yield. However, there is little information about the mode of action of CMF to control this disease. In the present study, we evaluated the role of CMF against $V$. dahliae and its mechanism of action in vitro and in vivo. In the laboratory tests, we observed that CMF could inhibit hyphal growth, microsclerotia germination, and reduce sporulation of $V$. dahliae. Further studies revealed that the biomass of $V$. dahliae in the root and hypocotyl of cotton seedlings treated with CMF were significantly reduced compared with the control, and these results could explain the decline in the disease index of cotton Verticillium wilt. Furthermore, those key genes involved in the phenylpropanoid metabolism pathway, resistancerelated genes defense, and nitric oxide signaling pathway were induced in cotton root and hypocotyl tissue when treated with CMF. These results suggest that CMF is a multifaceted micronutrient fertilizer with roles in inhibiting the growth, development, and pathogenicity of $V$. dahliae and promoting cotton growth.
\end{abstract}

Keywords: cotton; Verticillium dahliae; pathogenicity; micronutrient; prevention strategy

\section{Introduction}

Verticillium dahliae Kleb. is a devastating soilborne fungal pathogen with worldwide distribution, which threatens agricultural production in the long term. It is able to infect more than 200 known plant species besides cotton in the world [1-3]. Cotton, a primary natural fiber crop, is of great importance to the global textile industry [4]. Unfortunately, China suffers from tremendous yield losses of cotton in $V$. dahliae-infested soil annually [5]. Much research has been made to understand the interaction between cotton- $V$. dahliae and to control Verticillium wilt [6], such as breeding resistant cultivars [7], crop rotation [8], developing soil fumigants [9], and the use of chemical fungicides [10], as well as biological control [3]. Unfortunately, because of the scarcity of resistance in host germplasm, there are no highly resistant cotton cultivars [11]. Crop rotation cannot be widely promoted due to limited land resources [12]. The control effect of a biological control agent is unstable because of its dependence on the soil environment and climate [13]. To date, chemical fungicides have to be selected as the principal method to control $V$. dahliae in agricultural production [1]. However, long-term use of chemical fungicides not only poses 
a threat to the ecological environment and human health but also improves the resistance of $V$. dahliae [14]. Therefore, there is an urgent need to develop environmentally-friendly strategies for effective control of Verticillium wilt disease.

Up to now, micronutrients have been confirmed to have the potential to inhibit soilborne root pathogens on plants, and optimization of plant micronutrients is a sustainable approach to improve crop health $[10,15,16]$. Micronutrients not only affect the normal growth and development of plants but also directly or indirectly influence the susceptibility and disease resistance of plants in many ways [17]. Specific single micronutrients, such as $\mathrm{Fe}, \mathrm{Zn}, \mathrm{Mn}, \mathrm{Cu}, \mathrm{Se}, \mathrm{Si}$, have been proven to have a suppressive effect on many plant diseases [18-21]. The application of $\mathrm{Zn}$ micronutrient could significantly reduce the occurrence of winter wheat (Triticum aestivum) leaf rust (Puccinia recondita), and lower the symptoms of hop (Humulus lupulus) leaf roll disease, and effectively prevent corn (Zea mays) stalk rot (Fusarium) [22]. As an inorganic fungicide, $\mathrm{Cu}$ is a component of phenolase, which directly participates in the metabolism of phenols in plants, affects the synthesis of phytoalexins, and inhibits the germination and growth of fungal spores. Evidence demonstrated that spraying $\mathrm{Cu}$ micronutrient lowered leaf blight of gourd (Lagenaria siceraria) [23]. Likewise, Mn participates in the production of phenolic compounds and reduces the incidence of various diseases, such as poplar (Populus tomentosa) canker (Lonsdalea populi), soybean (Glycine max) virus disease, cabbage (Brassica oleracea) root swelling (Plasmodiophora brassicae), and cotton Verticillium wilt [24]. A reasonable application of multiple micronutrients can induce plant systemic resistance. It is of great significance to reduce pesticide consumption and environmental pollution [25]. A study found that the application of $\mathrm{P}, \mathrm{K}, \mathrm{Zn}$ fertilizers combined with the low-level application of $\mathrm{N}$ and Fe could significantly reduce pea (Pisum sativum) powdery mildew disease [26]. Besides, the combined application of $\mathrm{Zn}$ and Se fertilizers could increase the GSH-Px activity of millet (Panicum miliaceum) more than a single application and had a significant synergistic effect on the antioxidant enzyme activity of millet leaves and the yield [27]. Regular application of Mo and Ca fertilizers to tobacco (Nicotiniana tabacum) enhanced the defense of tobacco against bacterial wilt (Ralstonia solanacearum) and improved its resistance to bacterial wilt [21]. In summary, as a supplement to chemical fungicides and biological control measures, the combination of specific micronutrients can aid the control of plant diseases, increase crop yields, and obtain significant economic benefits.

Compound micronutrient fertilizer (CMF) was jointly developed by the Institute of Cotton Research of the Chinese Academy of Agricultural Sciences and the Puyang City Academy of Agricultural Sciences, produced by Puyang City Nongke Agrochemical Co., Ltd. whose merchandise name is Mianweike and the registration number is agricultural fertilizer (2009) No. 1406, and the main components are $\mathrm{Cu}, \mathrm{Zn}, \mathrm{Mn}$ micronutrients with a content of more than $10 \%$. In our previous study, CMF was used to prevent and control cotton Verticillium wilt by spraying or drip irrigation, with a control effect of over $40 \%$ and an increase in yield of 7.0 9.3\% in Alaer and Shihezi, Xinjiang, China [28]. However, there is little information about the mechanism of action of CMF to control cotton Verticillium wilt.

The objectives of this work were to analyze the effect of CMF on mycelial growth, microsclerotia germination, and sporulation of $V$. dahliae to evaluate the direct impact of $\mathrm{CMF}$ on the pathogen. Furthermore, we studied the expression of resistance-related genes in cotton treated with CMF to illuminate the induced resistance of cotton. Revealing these effects are of great importance to understand better the mechanism of the action of CMF against $V$. dahliae on cotton.

\section{Results}

\subsection{Inhibitory Effect of CMF on Mycelial Growth of V. dahliae}

To analyze the function of CMF in fungal growth and microsclerotia production, $V$. dahliae strain $\mathrm{Vd} 080$ was grown on potato dextrose agar (PDA). At 9 days post inoculation (dpi), all treatments of different concentrations of CMF led to a significant inhibition in hyphal growth and a significant reduction in melanin and microsclerotia production 
of $V$. dahliae strain Vd080 (Figure 1a). The growth inhibition rates of CMF on $V$. dahliae strain $\mathrm{Vd} 080$ were related to the concentration of CMF, with the respective inhibition rates of $25.57 \%, 37.50 \%, 49.63 \%, 59.63 \%$, and $68.01 \%$, corresponding to the concentrations of $0.16,0.31,0.63,2.50$, and $10.00 \mathrm{~g} / \mathrm{L}$ (Table 1 ). In addition, the regression equation was $\mathrm{Y}=0.5738 \mathrm{X}+4.9727, \mathrm{R}^{2}=0.9477(p<0.01) . \mathrm{EC}_{50}$ and $\mathrm{EC}_{95}$ values of $\mathrm{CMF}$ were $1.12 \mathrm{~g} / \mathrm{L}$ and $820.58 \mathrm{~g} / \mathrm{L}$, respectively.

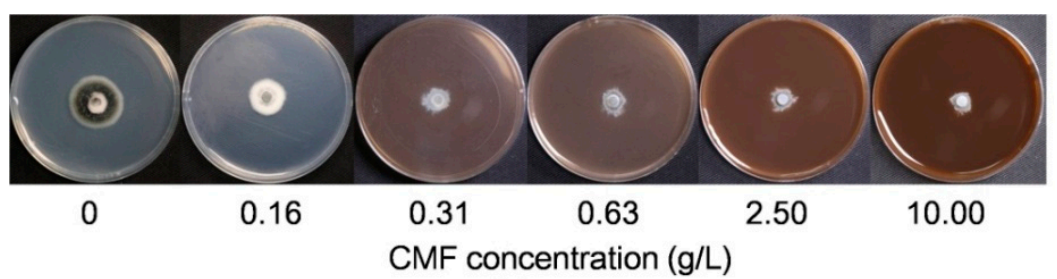

(a)

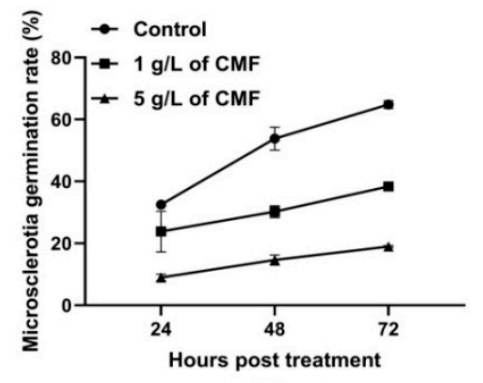

(b)

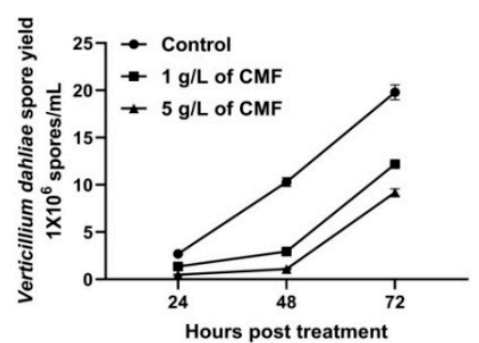

(c)

Figure 1. Influence of compound micronutrient fertilizer (CMF) on phenotypic characterization of $V$. dahliae. (a) Colony morphology of $V$. dahliae treated with $\operatorname{CMF}(0,0.16,0.31,0.63,2.50,10.00 \mathrm{~g} / \mathrm{L})$ on potato dextrose agar (PDA) at 9 days post inoculation (dpi). (b) Inhibition of CMF on microsclerotia germination of $V$. dahliae. (c) Effect of CMF on sporulation of $V$. dahliae. Means and standard errors were calculated from five independent experiments according to Tukey's honestly significant difference (HSD) test.

Table 1. Inhibitory effect of compound micronutrient fertilizer (CMF) on mycelial growth of $V$. dahliae.

\begin{tabular}{ccc}
\hline CMF Concentration $(\mathrm{g} / \mathrm{L})$ & Colony Diameter $(\mathbf{m m})$ & Growth Inhibition Rate (\%) \\
\hline 0 & $27.20 \pm 1.69 \mathrm{a}$ & $/$ \\
0.16 & $19.70 \pm 1.77 \mathrm{~b}$ & 27.57 \\
0.31 & $17.00 \pm 1.05 \mathrm{c}$ & 37.50 \\
0.63 & $13.70 \pm 0.67 \mathrm{~d}$ & 49.63 \\
2.50 & $10.90 \pm 0.74 \mathrm{e}$ & 59.93 \\
10.00 & $8.70 \pm 0.82 \mathrm{f}$ & 68.01
\end{tabular}

The data represent the mean \pm SE $(n=5)$. Data followed by different letters indicate statistically significant differences at the level of $p<0.05$ according to Tukey's HSD.

\subsection{Inhibition of CMF on Microsclerotia Germination of V. dahliae}

With the extension of culture time, the germination rates of microsclerotia gradually increased. Compared with the untreated control, the germination rates of microsclerotia treated with CMF were significantly lower. At $72 \mathrm{~h}$ post treatment (hpt), the microsclerotia germination rates of $V$. dahliae strain Vd080 treated with CMF concentrations of $1 \mathrm{~g} / \mathrm{L}$ and $5 \mathrm{~g} / \mathrm{L}$ were $38.33 \%$ and $18.93 \%$, respectively, with the inhibition ratios being $40.85 \%$ and $70.79 \%$, respectively (Figure $1 \mathrm{~b}$ ).

\subsection{Influence of CMF on Sporulation of V. dahliae}

As expected, CMF also had a pronounced inhibitory effect on the conidia production of $V$. dahliae. Regardless of $1 \mathrm{~g} / \mathrm{L}$ or $5 \mathrm{~g} / \mathrm{L}$ concentration of CMF treatment, sporulation of 
$V$. dahliae was significantly lower than the control. At $72 \mathrm{hpt}$, the spore yields of $V$. dahliae treated with CMF concentrations of $1 \mathrm{~g} / \mathrm{L}$ and $5 \mathrm{~g} / \mathrm{L}$ were $12.20 \times 10^{6}$ spores $/ \mathrm{mL}$ and $9.20 \times 10^{6}$ spores $/ \mathrm{mL}$, with the reduction rates of $38.38 \%$ and $53.53 \%$ compared to the control $\left(19.80 \times 10^{6}\right.$ spores $\left./ \mathrm{mL}\right)$, respectively (Figure $1 \mathrm{c}$ ).

\subsection{Suppression of Cotton Verticillium Wilt in the Greenhouse}

In the greenhouse trials, cotton plants treated with $1 \mathrm{~g} / \mathrm{L}$ of CMF reduced wilt development when assessed 24 days post spraying treatment (Figure 2a). The xylem of CMF-treated plants showed lighter vascular browning than that of the control (Figure $2 b$ ). The disease index (DI) of 17.44 for the CMF-treated plants, compared to 31.89 for the control. The control efficacy was $62.33 \%, 46.20 \%$, and $45.31 \%$ when assessed at 10,17 , and 24 days post spraying CMF (Figure 2c).

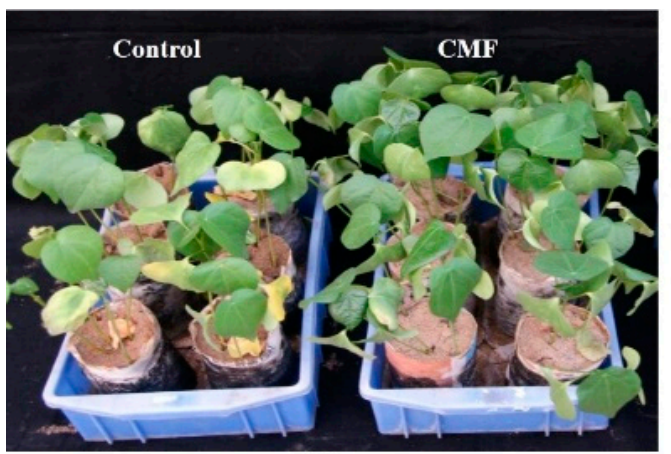

(a)

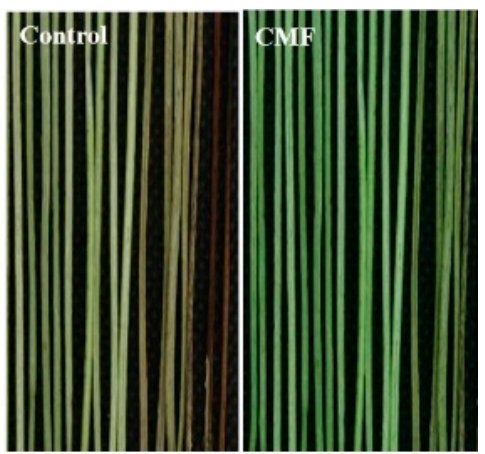

(b)

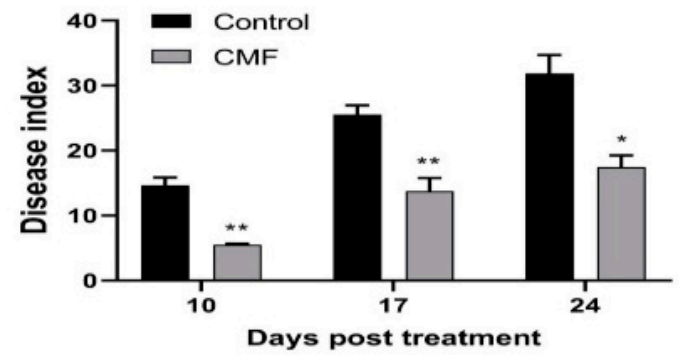

(c)

Figure 2. CMF protects cotton plants from $V$. dahliae infection in the greenhouse. (a) Cotton plants at 24 days post treatment with CMF after inoculation with $V$. dahliae. (b) Vascular browning found in xylem from infected cotton plants at $24 \mathrm{dpt}$. (c) Disease symptom progress from three replicate experiments in the greenhouse assay. Asterisks indicate statistically significant differences compared with control $\left({ }^{*} p<0.05\right.$ and $\left.{ }^{* *} p<0.01\right)$.

In addition, the qPCR results showed that the biomass of $V$. dahliae strain Vd080 in roots of infected cotton plants increased first and then decreased, with the peak at $48 \mathrm{~h}$ post treatment (hpt). At $48 \mathrm{hpt}$, the biomass of $V$. dahliae strain Vd080 in CMF-treated cotton plants only accounted for one-tenth of the untreated control (Figure 3a). In hypocotyl tissue, the $V$. dahliae biomasses with or without CMF treatment all increased over time, but the increase in CMF-treated cotton plants was slower than that of the control plants. At $96 \mathrm{hpt}$, the V. dahliae strain Vd080 biomass of the control was 4.26-fold compared to CMF treatment (Figure $3 \mathrm{~b}$ ). Collectively, these results proved that CMF has an inhibitory effect on the infection, colonization, and spread of $V$. dahliae on cotton. 


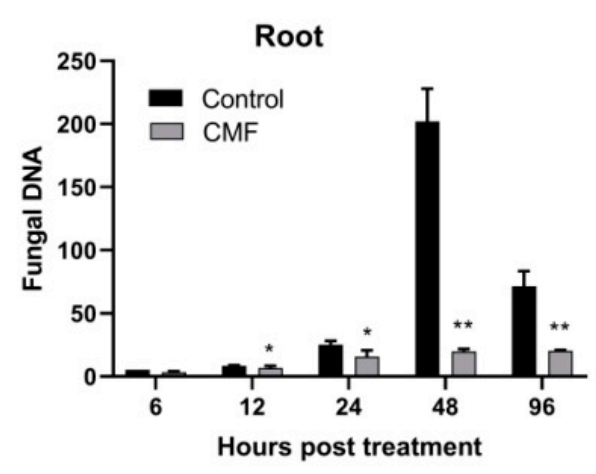

(a)

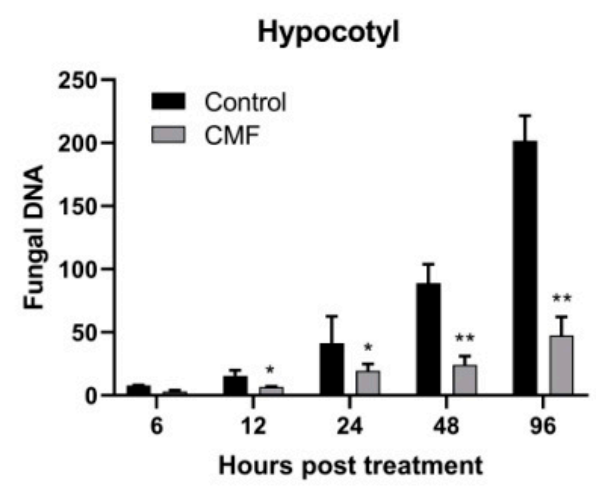

(b)

Figure 3. Detection of fungal biomass in infected cotton tissues. (a) Quantification of fungal DNA in root section. (b) Quantification of fungal DNA in hypocotyl tissue. Asterisks indicate statistically significant differences compared with control $\left({ }^{*} p<0.05\right.$ and $\left.{ }^{* *} p<0.01\right)$.

\subsection{Effect of CMF Treatment on Cotton Seedling Development}

There was no significant difference between the two treatments in root length and plant height when assessed 24 days after treatment, compared to the control (Table 2). Interestingly, the fresh weight of cotton seedlings was significantly increased by $14.53 \%$ compared to the control (Table 2).

Table 2. Effect of CMF on cotton biomass.

\begin{tabular}{cccc}
\hline Treatment & Root Length $\mathbf{( c m})$ & Plant Height $(\mathbf{c m})$ & Fresh Weight $(\mathbf{g})$ \\
\hline Control & $9.43 \pm 0.44 \mathrm{a}$ & $11.74 \pm 0.61 \mathrm{a}$ & $1.07 \pm 0.03 \mathrm{~b}$ \\
CMF & $9.53 \pm 0.11 \mathrm{a}$ & $11.35 \pm 1.18 \mathrm{a}$ & $1.23 \pm 0.06 \mathrm{a}$ \\
\hline
\end{tabular}

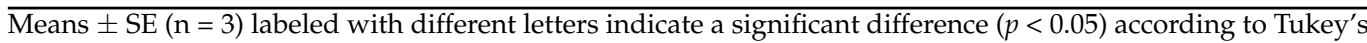
HSD test.

\subsection{Expression Analysis of Resistance-Related Genes}

Gene expression patterns varied over time and had specific expression in different plant tissues. As key genes of the lignin metabolism pathway, the genes of peroxidase, $P O D$; polyphenol oxidase, $P P O$; and phenylalanine ammonia lyase, $P A L$, were strongly upregulated in both root and hypocotyl tissues of cotton treated with CMF, compared to the control. In detail, the expression of $P O D$ in root and hypocotyl tissues reached its peak at $12 \mathrm{hpt}$ and $24 \mathrm{hpt}$, with the respective 1.7-fold and 2.1-fold compared to the control. Subsequently, its expression level declined (Figure 4a). The expression kinetics of $P P O$ and $P A L$ genes were similar to $P O D$. It was worth mentioning that the expression level of $P P O$ in hypocotyl tissue increased 55 times on average compared with those in root tissue. In addition, the gene expression level of $P P O$ in hypocotyl tissue of cotton treated with CMF was significantly higher than the control, with a 1.7 -fold compared to the control at $12 \mathrm{hpt}$ (Figure $4 \mathrm{~b}$ ). The expressions of $P O D, P P O$, and $P A L$ were all significantly upregulated in both root and hypocotyl tissues of those plants treated with CMF within 48 hpt compared with control plants (Figure 4c). 


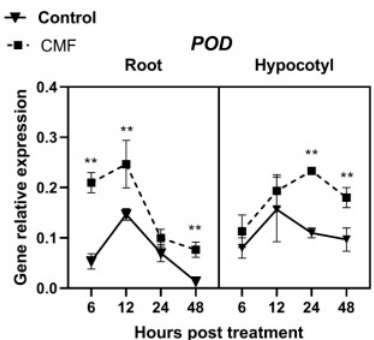

(a)

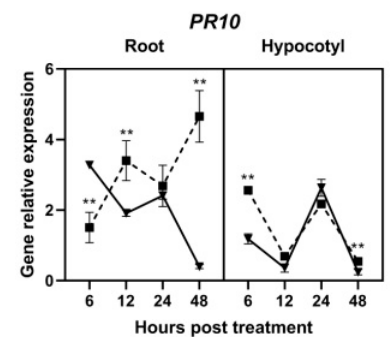

(d)

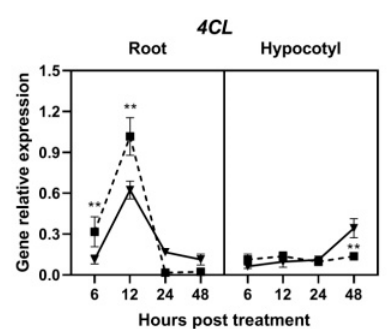

(g)

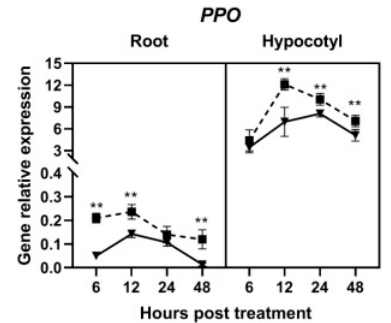

(b)

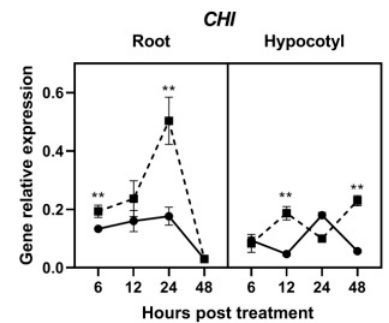

(e)

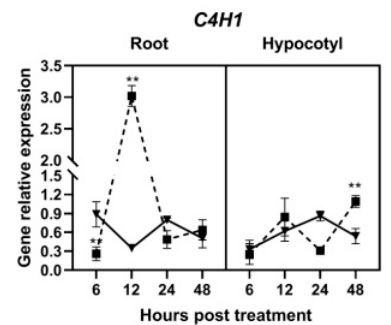

(h)

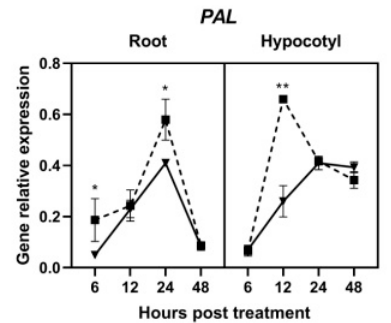

(c)

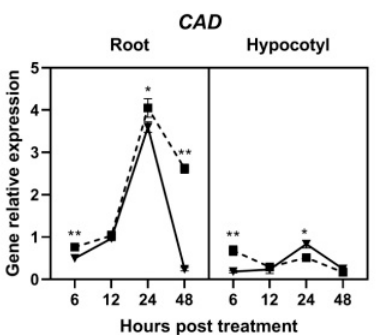

(f)

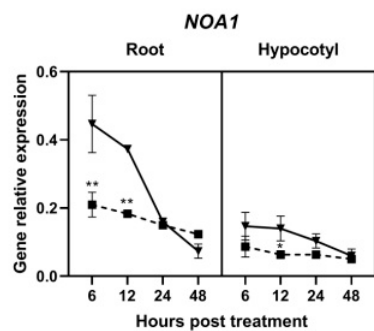

(i)

Figure 4. Induction of resistance-related gene expression in cotton treated with CMF after inoculation with $V$. dahliae. Samples of cotton root and hypocotyl tissues were collected 6, 12, 24, and 48 h post treatment. Data are means of three replicate experiments in the greenhouse assay. The bars represent the average induction $( \pm S E$ ) of gene transcripts normalized to the Ubiquitin gene for three replicates. Asterisks indicate statistically significant differences compared with control $\left({ }^{*} p<0.05\right.$ and $\left.{ }^{* *} p<0.01\right)$. (a) polyphenol oxidase, $P O D,(\mathbf{b})$ polyphenol oxidase, $P P O$, (c) phenylalanine ammonia lyase, $P A L$, (d) PR10, (e) basic chitinase, CHI, (f) cadinene synthase, CAD, (g) 4-coumaric acid-CoA ligase, 4CL, (h) cinnamic acid hydroxylase, C4H1, (i) nitric oxide associated 1, NOA1.

As a broad-spectrum resistance function gene, PR10; PR10 expression was upregulated in hypocotyl tissue with a trend of fall and rise, then fall and rise. This phenomenon occurred in both cotton treated or untreated with CMF. However, the expression of PR10 in root tissue of cotton treated with $\mathrm{CMF}$ was rise and fall, then rise and fall, opposite to the control, and with the highest expression of 11.6-fold to the control at $48 \mathrm{hpt}$ in root (Figure $4 \mathrm{~d}$ ). Transcription levels of basic chitinase, $C H I$, and cadinene synthase, $C A D$ genes were also upregulated at $24 \mathrm{hpt}$ in roots treated with $\mathrm{CMF}$, with respective increases of 2.8-fold and 1.1-fold compared to the control (Figure 4e,f). Similarly, the expression levels significantly increased by 5.0-fold and 7.9-fold over them in roots, respectively.

As key genes of the phenylpropanoid metabolic pathway, 4-coumaric acid-CoA ligase, $4 C L$, and cinnamic acid hydroxylase, $C 4 H 1$ expression was drastically upregulated in $\mathrm{CMF}$-treated cotton root during $12 \mathrm{hpt}$. Subsequently, their expression levels decreased significantly below those of mock-treated roots at $24 \mathrm{hpt}$, and their peak expression levels were 1.6 times and 8.6 times over the control, respectively. In CMF-treated cotton hypocotyl tissue, the expression levels of $4 \mathrm{CL}$ and $\mathrm{C} 4 \mathrm{H} 1$ were not significantly different from those of the control. Until $48 \mathrm{hpt}$, their expression increased and was significantly higher than the control (Figure 4g,h). 
NOA1 (Nitric oxide associated 1) involved in protein translation in the chloroplast has been indirectly linked to nitric oxide (NO) accumulation. Regardless of whether the cotton was treated or untreated with CMF, the expression level of NOA1 in root and hypocotyl tissues was downregulated. Furthermore, in cotton root treated with $\mathrm{CMF}$, the expression of NOA1 was significantly downregulated, with about one-half of the control at $6 \mathrm{hpt}$ (Figure 4i).

\subsection{Suppression of Cotton Verticillium Wilt in the Field}

For the CMF treatment, the DI values ranged from 6.50 to 16.61 , compared to corresponding values for the control from 17.60 to 35.52 , with a significant difference level, accompanied by the control efficacies of CMF from $63.05 \%$ to $53.24 \%$ (Figure 5). There were no plant samples with wilt scores of 3 and 4 in CMF treatment. This result demonstrates that CMF could effectively curb the further deterioration of diseased cotton plants.

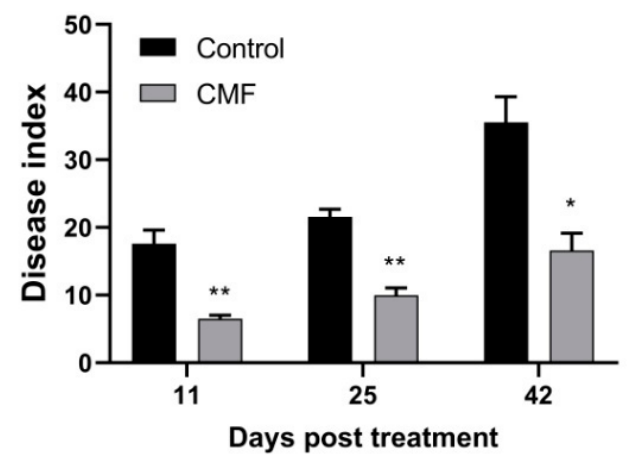

Figure 5. CMF protects cotton plants from $V$. dahliae infection in the field. Data are means of three replicate experiments in the field assay. Asterisks indicate statistically significant differences compared with control $\left({ }^{*} p<0.05\right.$ and ${ }^{* *} p<0.01$.).

Cotton yield results showed that the seed cotton weight of CMF treatment reached $2770.17 \mathrm{~kg} / \mathrm{ha}$, increasing $7 \%$ compared to the control $(2588.82 \mathrm{~kg} / \mathrm{ha})$. The increase in lint cotton yield was roughly the same as that of seed cotton, with an increase of $8.19 \%$. As an important element of cotton yield, single cotton boll weight treated with CMF increased by $6.75 \%$ compared to the control, but with no significant difference. Likewise, there was no significant difference in cotton lint percentage between the two treatments (Table 3).

Table 3. Effect of CMF on cotton yield parameters.

\begin{tabular}{ccccc}
\hline Treatment & $\begin{array}{c}\text { Seed Cotton } \\
\mathbf{( k g / h a )}\end{array}$ & $\begin{array}{c}\text { Lint Cotton } \\
\mathbf{( k g / h a )}\end{array}$ & $\begin{array}{c}\text { Lint Percentage } \\
\mathbf{( \% )}\end{array}$ & $\begin{array}{c}\text { Single Boll } \\
\text { Weight } \mathbf{( g )}\end{array}$ \\
\hline Control & $2588.82 \pm 64.61 \mathrm{~b}$ & $1043.24 \pm 43.92 \mathrm{~b}$ & $40.34 \pm 2.69 \mathrm{a}$ & $4.79 \pm 0.23 \mathrm{a}$ \\
CMF & $2770.17 \pm 46.69 \mathrm{a}$ & $1128.70 \pm 24.82 \mathrm{a}$ & $40.74 \pm 0.21 \mathrm{a}$ & $5.13 \pm 0.15 \mathrm{a}$ \\
\hline Means + SE $(\mathrm{n}=3)$ labeled with different letters indicate a sionificant difference $(p<0.05)$ according to Tukey's
\end{tabular}
HSD test.

\section{Discussion}

Micronutrients are necessary for the normal growth and development of plants. Reasonably balanced fertilization can make plants grow vigorously and enhance disease resistance [29]. In recent years, more and more attention has been paid to the harm of chemical fungicides on the environment and ecological balance [30]. Mounting evidence shows that some special micronutrients have the potential to control plant diseases $[15,18]$. Micronutrient elements, such as $\mathrm{Cu}$ and $\mathrm{Zn}$, are widely used in inorganic fungicides to directly resist the infection of pathogenic fungi, reduce the germination of spores, and the growth of pathogenic fungi $[16,31]$. In this study, we determined that CMF (the main components include $\mathrm{Cu}, \mathrm{Zn}, \mathrm{Mn}$ micronutrients) could inhibit mycelial growth and sporulation of $V$. dahliae (Figure 1). Furthermore, the regression equation of CMF was calculated, 
with $\mathrm{EC}_{50}$ and $\mathrm{EC}_{95}$ values of $1.12 \mathrm{~g} / \mathrm{L}$ and $820.58 \mathrm{~g} / \mathrm{L}$, respectively. These results will provide guidance for the prevention and control of cotton Verticillium wilt in production. A current study suggests that Se can reduce the pathogenicity of Sclerotinia sclerotiorum by inhibiting sclerotial formation and germination [10]. Besides, growing research show that micronutrients could promote plant growth, heighten biomass, and increase crop yield [15,16,32]. Similarly, this study suggests that the fresh weight of cotton seedlings treated with CMF was significantly increased by $14.53 \%$, and lint cotton yield increased by $8.19 \%$. Collectively, these results indicate that CMF could not only directly inhibit the growth of $V$. dahliae but also increase cotton biomass.

As the long-term survival resting structures of $V$. dahliae, microsclerotia play a critical role in the disease cycle as primary sources of infection [33]. The synthesis of microsclerotia and accumulation of melanin are directly coupled with the pathogenicity or virulence of $V$. dahliae, which are always considered important targets for Verticillium wilt control [34]. Unfortunately, the microsclerotia have a strong ability to resist adversity and can survive for more than 10 years in the field soil [1,35]. Hence, inhibiting microsclerotia formation, on the one hand, can directly reduce the initial infection; on the other hand, lower the germination of hyphae, which is considered an effective approach to control $V$. dahliae. In this study, the formations of microsclerotia and melanin in $V$. dahliae were almost completely inhibited after CMF treatment. Furthermore, CMF also has an inhibitory effect on the microsclerotia germination of $V$. dahliae (Figure $1 \mathrm{~b}$ ). This agrees with previous findings that Se inhibits mycelial growth and sclerotial formation of S. sclerotiorum [10]. These findings show that CMF may reduce the pathogenicity of $V$. dahliae by inhibiting the formation of microsclerotia.

Verticillium wilt is caused by the systemic colonization of $V$. dahliae in plant vascular tissues, and plant roots usually serve as the first battleground between $V$. dahliae and plant host [36]. The colonization of $V$. dahliae on cotton roots directly affects the incidence of cotton Verticillium wilt [37]. Next, the xylem is the second battlefield of $V$. dahliae and plant host that compete for nutrition [38]. As a new type of pathogen antagonist, phosphate can reduce the colonization and spread of a variety of pathogenic fungus in plants [39]. Similarly, CMF could reduce the colonization of $V$. dahliae in cotton root and the spread in hypocotyl by detecting the biomass of $V$. dahliae in cotton tissues (Figure 3), resulting in severely impaired virulence on cotton (Figure 2a). Even in the field that was previously infested with Verticillium wilt, this new micronutrient fertilizer significantly reduced wilt development, and the suppressive effect was more than $53 \%$ and could last up to 42 days (Figure 5). These findings suggest that CMF not only improves the ability of cotton to resist the infection of $V$. dahliae, but also reduce pathogenicity of $V$. dahliae.

In general, under biological stress conditions, reactive oxygen species (ROS) are widely found in organisms, which play an important role in fighting against pathogens [16,40]. After plant recognition of pathogen attack, a rapid oxidative burst of oxygen radicals is needed to trigger plant defense mechanisms and induce $P O D, P P O, S O D$ antioxidant enzyme genes to participate in the regulation of oxygen radicals [41]. Besides, POD, PPO together with $P A L, 4 C L$, and $C 4 H 1$ participate in the phenylpropanoid metabolic pathway, playing an important role in the plant defense response [42,43]. The enhanced expression of defense-related genes contributes to the activation of plant defense systems [44]. Similarly, foliar spraying with phosphate can not only inhibit cucumber (Cucumis sativus) powdery mildew (Podosphaera xanthii) by increasing the activity of related defense enzymes but also improve cucumber's local and systemic resistance to powdery mildew and other diseases [45]. In our study, the expression levels of $P O D, P P O, P A L, 4 C L$, and C4H1 genes in the root and hypocotyl tissues of cotton seedlings treated with CMF were all upregulated, but the levels of the gene expression vary in different tissues, especially the expression level of PPO in the hypocotyl was 55 times higher than in the root (Figure 4). Therefore, these results indicate that CMF could induce cotton to acquire local and systemic resistance by increasing the expression of key genes of the phenylpropanoid metabolic pathway to inhibit the harm of $V$. dahliae. In addition, many disease-resistant genes were induced by 
micronutrients against pathogen infection $[46,47]$. In this study, we provide evidences that $\mathrm{CMF}$ induces a varying degree increase of resistance-related genes transcripts, including $P R 10, C H I$, and CAD. It is noteworthy that the nitric oxide (NO) signaling pathway cofunctions with the ROS signaling pathway in plant biotic interactions [48]. The expression of $N b N O A 1$ was downregulated because of a significant decrease in NO accumulation [49]. In the present study, NOA1 was also downregulated due to CMF treatment reducing $\mathrm{NO}$ accumulation. In summary, we may conclude that the mechanism of action of CMF induced cotton to respond to the invasion of $V$. dahliae is complicated, involving the phenylpropanoid metabolism pathway, resistance-related genes defense, and NO signaling pathway. Furthermore, CMF is also promoting plant growth and development. Further research is needed to investigate whether the defense induced by CMF depends on the natural defense mechanism of plants.

\section{Materials and Methods}

\subsection{Cotton Cultivar, Fungal Strain and Culture Conditions}

The cotton cultivar used in these tests was Lumianyan 21, which is tolerant to $V$. dahliae. The $V$. dahliae strain Vd080, which was isolated from cotton collected in Xinji, Hebei, China, was single-spore isolated and stored at $-80{ }^{\circ} \mathrm{C}$ in $20 \%(v / v)$ glycerol. Cultures were activated on a potato dextrose agar medium to observe biological characteristics. To induce conidia formation for the infection assays, isolates were incubated in liquid Czapek medium at $25^{\circ} \mathrm{C}$ with shaking at $150 \mathrm{r} / \mathrm{min}$ [50].

\subsection{Preparation of V. dahliae Fermentation Broth}

The V. dahliae strain Vd080 was inoculated in liquid Czapek medium, cultured on a constant temperature shaker, $150 \mathrm{r} / \mathrm{min}, 25{ }^{\circ} \mathrm{C}$ for $5-7$ days. Next, V. dahliae strain Vd080 sporulation was calculated using a hemocytometer (QIUJING, Shanghai, China) and diluted with distilled water to $1 \times 10^{7} \mathrm{CFU} / \mathrm{mL}$ [51].

\subsection{Assessing the Effect of CMF on the Growth Rate of V. dahliae}

A mycelial disk of $V$. dahliae strain Vd080 (4 mm diameter) was placed in the center of the PDA medium plate, which contained gradient configuration $(0,0.16,0.31,0.63$, 2.50 , and $10.00 \mathrm{~g} / \mathrm{L}$ ) of CMF. The plate was then immediately sealed with plastic film and incubated in the dark at $25^{\circ} \mathrm{C}$ for 9 days. Five repeats were set for each concentration of CMF. The $V$. dahliae colony diameter was measured on 7- and 9-days post inoculation. The growth inhibition rate $(\%)=($ control colony diameter - treated colony diameter $) /$ control colony diameter $\times 100$, and the $\mathrm{EC}_{50}$ and $\mathrm{EC}_{95}$ values of $\mathrm{CMF}$ were calculated [42].

\subsection{Effect of CMF on the Microsclerotia Germination of V. dahliae}

The culture of microsclerotia and preparation its suspension were performed as described previously [52]. Microsclerotia suspension $(100 \mu \mathrm{L})$ and the same amount of liquid Czapek medium containing different concentrations of CMF were mixed and cultured at $20^{\circ} \mathrm{C}$ in the dark. The germination rates of microsclerotia at 24,48 , and $72 \mathrm{~h}$ post treatment were estimated by a microscope (Toshiba, Tokyo, Japan) with a $40 \times$ eyepiece. The numbers of 100 microsclerotia were observed each time, and the length of the germ tube of the microsclerotia exceeded half regarded as germination.

\subsection{Assessing the Effect of CMF on the Sporulation of V. dahliae}

Spore concentration of $V$. dahliae strain $\mathrm{Vd} 080$ was adjusted to $1 \times 10^{7} \mathrm{CFU} / \mathrm{mL}$, then $5 \mu \mathrm{L}$ of the spore suspension was added to liquid Czapek medium with CMF concentrations equal to $1 \mathrm{~g} / \mathrm{L}$ and $5 \mathrm{~g} / \mathrm{L}$, and incubated on a constant temperature shaker at $25^{\circ} \mathrm{C}$ with shaking at $150 \mathrm{r} / \mathrm{min}$. The experiment was performed five times. Spore yields at 24,48 , and $72 \mathrm{hpt}$ were estimated with a hemocytometer [37]. 


\subsection{Suppressive Effect of CMF on V. dahliae in the Greenhouse}

Cotton seeds were sown in paper pots $(6 \mathrm{~cm}$ in diameter and $10 \mathrm{~cm}$ in height, without a bottom) filled with an autoclaved substrate (vol/vol, vermiculite/sand $=6 / 4)$. The inoculum concentration of $V$. dahliae strain Vd080 was adjusted to $1 \times 10^{7} \mathrm{CFU} / \mathrm{mL}$ and inoculated onto 25-30 cotton seedlings at the first euphylla stage by immersing the seedlings ${ }^{\prime}$ roots in the $V$. dahliae strain Vd080 conidial suspension [53]. The experiment was performed three times. The cotton seedlings began to sporadically exhibited chlorosis and wilting at 4 days post inoculation. Meanwhile, CMF was diluted with sterile deionized water (SDW) to the concentration $1 \mathrm{~g} / \mathrm{L}$. The cotton seedlings were sprayed with CMF suspension via a handheld sprayer. Control plants were sprayed with SDW. The cotton seedlings were cultivated in a standard greenhouse at $25-30^{\circ} \mathrm{C}$ under a $16-\mathrm{h} / 8$-h light-dark photoperiod. Disease progress was recorded 10,17, and 24 days post spraying treatment. The classification of Verticillium wilt was as follows: $0=$ healthy plant; $1=$ one or two cotyledons showing symptoms; 2 = both cotyledons and one true leaf showing symptoms; $3=$ both cotyledons and two true leaves showing symptoms; $4=$ plant died. The disease index was calculated as follows: DI $\left.=\left(0 n_{0}+1 n_{1}+2 n_{2}+3 n_{3}+4 n_{4}\right) / 4 n\right) \times 100$, where $n_{0}-n_{4}$ were the numbers of plants with each of the corresponding disease ratings, and $\mathrm{n}$ was the total number of plants assessed [53]. Meanwhile, the cotton seedlings' biological indicators, including root length, plant height, and fresh weight, were measured at $24 \mathrm{dpt}$.

\section{7. qPCR Quantification of Fungal Biomass in Plant Tissue}

To quantify pathogen colonization level in root and hypocotyl tissues treated with CMF, V. dahliae strain Vd080 biomass on cotton plants, it was estimated by quantitative PCR. The root and hypocotyl tissues of cotton were harvested by cutting with a sharp scissor at 6, 12, 24, 48, and $96 \mathrm{~h}$ post spraying treatment (hpt) as described above. Plant tissues were sterilized for $10 \mathrm{~min}$ with $70 \%$ ethanol and rinsed three times with sterile water, five cotton plants as a treatment. Fungi-plants mixed DNA was extracted using the hexadecyltrimethylammonium bromide method (CTAB), and DNA concentration of each sample was measured by NanoDrop 2000 (Thermo Scientific Corporation, Beijing, China) and adjusted to $50 \mathrm{ng} / \mu \mathrm{L}$ for the qPCR reaction [54]. Primers Vd $\beta \mathrm{t}-\mathrm{F}$ and Vd $\beta \mathrm{t}-\mathrm{R}$ were designed based on the $V$. dahliae $\beta$-tubulin gene [55]. The endogenous control G. hirsutum actin gene was amplified using primer act-F and act-R [37] (Table 4). Cycle thresholds were determined in three biological replicates per sample using LightCycler 480 system (Roche Diagnostics, Mannheim, Germany) and the TOP SYBR Green qPCR SuperMix (TransGEN, Beijing, China) as the reporter dye. Real-time qPCR was run for 45 cycles. Initial denaturation and enzyme activation were carried out at $94{ }^{\circ} \mathrm{C}$ for $30 \mathrm{~s}$, denaturation at $95^{\circ} \mathrm{C}$ for $5 \mathrm{~s}$, annealing at $60^{\circ} \mathrm{C}$ for $15 \mathrm{~s}$, and elongation at $72{ }^{\circ} \mathrm{C}$ for $10 \mathrm{~s}$.

\subsection{Expression Analysis of Resistance-Related Genes by qRT-PCR}

The relative transcript levels of resistance-related genes were determined with a quantitative reverse transcription PCR (qRT-PCR) method. The root and hypocotyl tissues of cotton were harvested at 6,12, 24, 48, and $96 \mathrm{hpt}$, as mentioned above. Total RNA was extracted from cotton Lumianyan 21 using an RNAprep Pure Plant Kit (Tiangen, Beijing, China) and reversely transcribed into cDNA using the PrimeScript ${ }^{\mathrm{TM}}$ II 1st Strand cDNA Synthesis Kit (Takara, Japan). The G. hirsutum Ubiquitin gene was used as an endogenous reference for the normalization of cotton mRNA [56]. qRT-PCR was performed to quantify the transcript levels of the following genes: three key genes in the lignin metabolism pathway (peroxidase, $P O D$; polyphenol oxidase, $P P O$; and phenylalanine ammonia lyase, $P A L$ ), three pathogenesis-related (PR) genes (disease-related protein gene, PR10; basic chitinase, $\mathrm{CHI}$; and cadinene synthase, $C A D$ ); two core genes in the phenylpropanoid metabolic pathway (4-coumaric acid-CoA ligase, $4 C L$, and cinnamic acid hydroxylase, $\mathrm{C} 4 \mathrm{H1}$ ) and an important gene responding to $\mathrm{NO}$ signaling pathway (nitric oxide associated 1, NOA1) with specific primers (Table 4). 
Table 4. qPCR detection of relative gene expressions.

\begin{tabular}{|c|c|}
\hline Gene Name & Primer Sequence $\left(5^{\prime}-3^{\prime}\right)$ \\
\hline \multirow{3}{*}{$V d \beta t$} & qPCR quantification of fungal biomass \\
\hline & F: AACAACAGTCCGATGGATAATTC \\
\hline & R: GTACCGGGCTCGAGATCG \\
\hline \multirow[t]{2}{*}{ actin } & F: CCTATGTTGCCCTGGACTATGAGC \\
\hline & R: GGACAACGGAATCTCTCAGCTCC \\
\hline \multirow{3}{*}{$P O D$} & qRT-PCR detection of genes relative expression \\
\hline & F: CCGCATAACCATCACAAG \\
\hline & R: АСТСТСАТСАССТTCAАCA \\
\hline \multirow[t]{2}{*}{ PPO } & F: ATATCCTTGTTCTGTCTGCTA \\
\hline & R: CTCCTTCTACCGTCTCTTC \\
\hline \multirow[t]{2}{*}{$P A L$} & F: TGGTGGCTGAGTTTAGGAAA \\
\hline & R: TGAGTGAGGCAATGTGTGA \\
\hline \multirow[t]{2}{*}{ PR10 } & F: ATGATTGAAGGTCGGCCTTTAGGG \\
\hline & R: CAGCTGCCACAAACTGGTTCTCAT \\
\hline \multirow[t]{2}{*}{$\mathrm{CHI}$} & F: CTTAGCCCAAACTTCCCA \\
\hline & R: TACATTGAGTCCACCGAGAC \\
\hline \multirow[t]{2}{*}{$C A D$} & F: TAACAACAATGATGCCGAGAA \\
\hline & R: ATGGTCCAAAGATGCTACTGC \\
\hline \multirow[t]{2}{*}{$4 C L$} & F: ATTCAAAAGGGAGATGCC \\
\hline & R: GAGAAGGGCAAAGCAACA \\
\hline \multirow[t]{2}{*}{ C4H1 } & F: CCGAACCCGACACCCATAAGC \\
\hline & R: GCAGGGATGTCATACCCACCAAG \\
\hline \multirow[t]{2}{*}{ NOA1 } & F: GAGGATGCTGAAAGACCTGCTA \\
\hline & R: TCTCAACTGGCTTGGGTACATG \\
\hline \multirow[t]{2}{*}{ Ubiquitin } & F: GAGTCTTCGGACACCATTG \\
\hline & R: CTTGACCTTCTTCTTCTTGTGC \\
\hline
\end{tabular}

4.9. Control Efficacy of CMF Against Cotton Verticillium Wilt and Increasing Yield in the Field

Field experiments were carried out in the artificial disease nursery located in Anyang, Henan, China $\left(36^{\circ} 05^{\prime} 19.46^{\prime \prime} \mathrm{N}, 114^{\circ} 30^{\prime} 47.21^{\prime \prime} \mathrm{E}\right)$. The field has more than 20 years of cotton crops and is to a serious Verticillium wilt field. Cotton (cv. Lumianyan 21) seeds were sown manually on 30 April 2020. The planting pattern was $80 \mathrm{~cm}$ equal row with $26 \mathrm{~cm}$ plant spacing and a density of 48,000 plants/ha. There were two treatments, including spraying CMF or not. Each replicate plot had 6 rows of $8 \mathrm{~m}$ in length, containing about 200 cotton plants. Both treatments were repeated three times. CMF was sprayed twice on 29 June and 15 July by using an artificial sprayer at a concentration of $1 \mathrm{~g} / \mathrm{L}$, the same amount of water as the control. Symptoms of Verticillium wilt on cotton were investigated at 11,25 , and 42 days post the first spraying CMF. Every cotton plant was listed, and the Verticillium wilt disease grade was continuously recorded. The classification of Verticillium wilt was as follows: $0=$ no symptoms, $1=\leq 33 \%, 2=>33 \%$ and $\leq 66 \%, 3=>66 \%$ and $\leq 99 \%$, and $4=>99 \%$ leaves with chlorosis wilt symptoms [53]. On 30 September, each plot was manually harvested, and the cotton yield was measured, including seed cotton weight, lint cotton weight, and single boll weight.

\subsection{Statistical Analysis}

The mean and standard error (SE) of all results were calculated, and one-way ANOVA and Tukey's honestly significant difference (Tukey's HSD) tests were performed using GraphPad Prism 8 to generate $p$-values. Significant differences are indicated with asterisks: ${ }^{*} p<0.05$ and ${ }^{* *} p<0.01$.

Author Contributions: Y.Z. and H.Z. designed the experiment. Y.Z. and F.W. implemented and collected the data. Y.Z. analyzed the results and prepared the manuscript. L.Z., Z.F., H.G., H.F., and Y.Y. revised the manuscript. All authors revised and approved the final manuscript. All authors have read and agreed to the published version of the manuscript. 
Funding: This work was supported by the Agricultural Science and Technology Innovation Program of the Chinese Academy of Agricultural Sciences.

Institutional Review Board Statement: Not applicable.

Informed Consent Statement: Not applicable.

Data Availability Statement: The data used to support the findings of this study are available from the corresponding author upon request.

Acknowledgments: We deeply appreciate the great support of all teachers and students in the research team throughout the research period.

Conflicts of Interest: The authors declare no conflict of interest.

\section{References}

1. Klosterman, S.J.; Atallah, Z.K.; Vallad, G.E.; Subbarao, K.V. Diversity, pathogenicity, and management of verticillium species. Annu. Rev. Phytopathol. 2009, 47, 39-62. [CrossRef] [PubMed]

2. Chen, J.-Y.; Liu, C.; Gui, Y.-J.; Si, K.-W.; Zhang, D.-D.; Wang, J.; Short, D.P.G.; Huang, J.-Q.; Li, N.I.; Yong, L.; et al. Comparative genomics reveals cotton-specific virulence factors in flexible genomic regions in Verticillium dahliae and evidence of hosrizontal gene transfer from Fusarium. New Phytol. 2018, 217, 756-770. [CrossRef] [PubMed]

3. Zhang, J.; Yu, X.; Zhang, C.; Zhang, Q.; Sun, Y.; Zhu, H.; Canming, T. Pectin lyase enhances cotton resistance to Verticillium wilt by inducing cell apoptosis of Verticillium dahliae. J. Hazard. Mater. 2021, 404, 124029. [CrossRef] [PubMed]

4. Campbell, B.T.; Saha, S.; Du, X.; Jia, Y.; Constable, G.; Dillon, S.; Abdurakhmonov, I.Y.; Abdukarimov, A.; Rizaeva, S.M.; Abdullaev, A.; et al. Status of the global cotton germplasm resources. Crop Sci. 2010, 50, 1161-1179. [CrossRef]

5. Pegg, G.F.; Brady, B.L. "Control” in Verticillium wilts. In Verticillium Wilts; CABI: New York, NY, USA, 2002; Volume 151, pp. 109-110.

6. Barbara, D.J. Verticillium Wilts. Physiol. Mol. Plant Pathol. 2003, 62, 51-52. [CrossRef]

7. Gao, X.; Wheeler, T.; Li, Z.; Kenerley, C.M.; He, P.; Shan, L. Silencing GhNDR1 and GhMKK2 compromises cotton resistance to Verticillium wilt. Plant J. 2011, 66, 293-305. [CrossRef]

8. Bhat, R.G.; Subbarao, K.V. Host range specificity in verticillium dahliae. Phytopathology 1999, 89, 1218-1225. [CrossRef]

9. Duniway, J.M. Status of chemical alternatives to methyl bromide for pre-plant fumigation of soil. Phytopathology 2002, 92, 1337-1343. [CrossRef]

10. Cheng, Q.; Hu, C.; Jia, W.; Cai, M.; Zhao, Y.; Tang, Y.; Yang, D.; Zhou, Y.; Sun, X.; Zhao, X. Selenium reduces the pathogenicity of Sclerotinia sclerotiorum by inhibiting sclerotial formation and germination. Ecotoxicol. Environ. Saf. 2019, 183, 109503. [CrossRef]

11. Zhao, Y.-L.; Zhou, T.-T.; Guo, H.-S. Hyphopodium-specific VdNoxB/VdPls1-dependent ROS-Ca2+ signaling is required for plant infection by verticillium dahliae. PLoS Pathog. 2016, 12, e1005793. [CrossRef]

12. Subbarao, K.V.; Kabir, Z.; Martin, F.N.; Koike, S.T. Management of soilborne diseases in strawberry using vegetable rotations. Plant Dis. 2007, 91, 964-972. [CrossRef] [PubMed]

13. Busby, P.E.; Ridout, M.; Newcombe, G. Fungal endophytes: Modifiers of plant disease. Plant Mol. Biol. 2016, 90, 645-655. [CrossRef] [PubMed]

14. Komárek, M.; Čadková, E.; Chrastný, V.; Bordas, F.; Bollinger, J.C. Contamination of vineyard soils with fungicides: A review of environmental and toxicological aspects. Environ. Int. 2010, 36, 138-151. [CrossRef] [PubMed]

15. Elsherbiny, E.A.; Taher, M.A. Silicon induces resistance to postharvest rot of carrot caused by Sclerotinia sclerotiorum and the possible of defense mechanisms. Postharvest Biol. Technol. 2018, 140, 11-17. [CrossRef]

16. Cabot, C.; Martos, S.; Llugany, M.; Gallego, B.; Tolrà, R.; Poschenrieder, C. A role for Zinc in plant defense against pathogens and herbivores. Front. Plant Sci. 2019, 10, 1171. [CrossRef]

17. Jung, H.W.; Tschaplinski, T.J.; Wang, L.; Glazebrook, J.; Greenberg, J.T. Priming in systemic plant immunity. Science 2009, 324, 89-91. [CrossRef]

18. Cai, H.; Tao, N.; Guo, C. Systematic Investigation of the Effects of Macro-elements and Iron on Soybean Plant Response to Fusarium oxysporum Infection. Plant Pathol. J. 2020, 36, 398-405.

19. Dordas, C. Role of nutrients in controlling plant diseases in sustainable agriculture. A review. Agron. Sustain. Dev. 2008, 28, 33-46. [CrossRef]

20. Debona, D.; Rodrigues, F.A.; Datnoff, L.E. Silicon's role in abiotic and biotic plant stresses. Annu. Rev. Phytopathol. 2017, 55, 85-107. [CrossRef]

21. Fones, H.; Preston, G.M. The impact of transition metals on bacterial plant disease. FEMS Microbiol. Rev. 2013, 37, 495-519. [CrossRef]

22. Rossbauer, G.; Zwack, F. New ways in the fight against leaf curls of hops. Zinc deficiency: Effect on the growth of hops, reasons and possibilities of control. Hopfen Rundschau 1987, 37, 47-50. (In German)

23. Bhargava, A.K.; Singh, R.D. Effect of nitrogenous fertilizers and trace elements on the severity of Alternaria blight of bottle gourd. Work. Pap. 1992, 54, 122-123. 
24. Fernando, D.R.; Baker, A.J.M.; Woodrow, I.E. Physiological responses in Macadamia integrifolia on exposure to manganese treatment. Aust. J. Bot. 2009, 57, 406-413. [CrossRef]

25. Yao, Y.A.; Wang, J.; Ma, X.; Lutts, S.; Sun, C.; Ma, J.; Yang, Y.; Achal, V.; Xu, G. Proteomic analysis of MN-induced resistance to powdery mildew in grapevine. J. Exp. Bot. 2012, 63, 5155-5170. [CrossRef] [PubMed]

26. Sindha, G.S. Effect of macro and micro nutrients on the development of powdery mildew of pea. Indian J. Mycol. Plant Pathol. $1989,19,219-221$.

27. Souza, G.A.; Hart, J.J.; Carvalho, J.G.; Rutzke, M.A.; Albrecht, J.C.; Guilherme, L.R.G.; Kochian, L.V.; Li, L. Genotypic variation of zinc and selenium concentration in grains of Brazilian wheat lines. Plant Sci. 2014, 224, 27-35. [CrossRef]

28. Shi, Y.Q.; Ma, Y.H.; Liu, A.Z.; Feng, Z.L.; Feng, H.J.; Zhao, L.H.; Wei, F.; Zhu, H.Q. Preliminary report on the control effect of spraying and drip irrigation with Mianweike to verticillium wilt in cotton field of Xinjiang. China Cotton 2020, 47, 19-21.

29. Rahman, A.; Wallis, C.M.; Uddin, W. Silicon-Induced Systemic Defense Responses in Perennial Ryegrass Against Infection by Magnaporthe oryzae. Phytopathology 2015, 105, 748-757. [CrossRef]

30. Yaganza, E.S.; Tweddell, R.J.; Arul, J. Postharvest application of organic and inorganic salts to control potato (Solanum tuberosuml.) Storage soft rot: Plant tissue-salt physicochemical interactions. J. Agric. Food Chem. 2014, 62, 9223-9231. [CrossRef]

31. Dabash, T.S.; El, S.A.I.; Ibrahim, N.A.; Radwan, I.A.; Ali, A.A. Relation between fertilizers and white rot disease of onion with reference to the rhizosphere [Egypt]. Agric. Res. Rev. 1985, 63, 99-110.

32. Huber, D.M.; Haneklaus, S. Managing nutrition to control plant disease. Landbauforschung Volkenrode 2007, 57, 313.

33. Fradin, E.F.; Thomma, B.P.H.J. Physiology and molecular aspects of Verticillium wilt diseases caused by V. dahliae and V. albo-atrum. Mol. Plant Pathol. 2006, 7, 71-86. [CrossRef] [PubMed]

34. Debode, J.; Maeyer, K.D.; Perneel, M.; Pannecoucque, J.; Hfte, M. Biosurfactants are involved in the biological control of verticillium microsclerotia by pseudomonas spp. J. Appl. Microbiol. 2010, 103, 1184-1196. [CrossRef] [PubMed]

35. Isaac, I.; MacGarvie, Q. Dormancy and germination of resting structures of Verticillium spp. Trans. Br. Mycol. Soc. 1966, 49, 669-IN16. [CrossRef]

36. Luo, X.; Xie, C.; Dong, J.; Yang, X.; Sui, A. Interactions between Verticillium dahliae and its host: Vegetative growth, pathogenicity, plant immunity. Appl. Microbiol. Biotechnol. 2014, 98, 6921-6932. [CrossRef]

37. Zhang, Y.-L.; Li, Z.-F.; Feng, Z.-L.; Feng, H.-J.; Shi, Y.-Q.; Zhao, L.-H.; Zhang, X.-L.; Zhu, H.-Q. Functional analysis of the pathogenicity-related gene vdpr1 in the vascular wilt fungus verticillium dahliae. PLoS ONE 2016, 11, e0166000. [CrossRef]

38. Zhou, T.-T.; Zhao, Y.-L.; Guo, H.-S. Secretory proteins are delivered to the septin-organized penetration interface during root infection by Verticillium dahliae. PLoS Pathog. 2017, 13, e1006275. [CrossRef]

39. Thao, H.T.B.; Yamakawa, T.; Shibata, K.; Sarr, P.S.; Myint, A.K. Growth response of komatsuna (Brassica rapa var peruvirids) to root and foliar applications of phosphite. Plant Soil. 2008, 308, 1-10. [CrossRef]

40. Gadjev, I.; Vanderauwera, S.; Gechev, T.S.; Laloi, C.; Minkov, I.N.; Shulaev, V.; Apel, K.; Inzé, D.; Mittler, R.; Van Breusegem, F. Transcriptomic footprints disclose specificity of reactive oxygen species signaling in arabidopsis. Plant Physiol. 2006, 141, 436-445. [CrossRef]

41. Noman, A.; Ali, Q.; Maqsood, J.; Iqbal, N.; Javed, M.T.; Rasool, N.; Naseem, J. Deciphering physio-biochemical, yield, and nutritional quality attributes of water-stressed radish (Raphanus sativus L.) plants grown from Zn-Lys primed seeds. Chemosphere 2018, 195, 175-189. [CrossRef]

42. Wei, F.; Zhang, Y.; Shi, Y.; Feng, H.; Zhao, L.; Feng, Z.; Zhu, H. Evaluation of the biocontrol potential of endophytic fungus fusarium solani CEF559 against verticillium dahliae in cotton plant. BioMed Res. Int. 2019, 2019, 3187943. [CrossRef] [PubMed]

43. Xu, L.; Zhu, L.; Tu, L.; Liu, L.; Yuan, D.; Jin, L.; Long, L.; Zhang, X. Lignin metabolism has a central role in the resistance of cotton to the wilt fungus Verticillium dahliae as revealed by RNA-Seq-dependent transcriptional analysis and histochemistry. J. Exp. Bot. 2011, 62, 5607-5621. [CrossRef] [PubMed]

44. Lin, J.; Gong, D.; Zhu, S.; Zhang, L.; Zhang, L. Expression of PPO and POD genes and contents of polyphenolic compounds in harvested mango fruits in relation to Benzothiadiazole-induced defense against anthracnose. Sci. Hortic. 2011, 130, 85-89. [CrossRef]

45. Reuveni, M.; Agapov, V.; Reuveni, R. Controlling powdery mildew caused by Sphaerotheca fuliginea in cucumber by foliar sprays of phosphate and potassium salts. Crop Prot. 1996, 15, 49-53. [CrossRef]

46. Shaban, M.; Miao, Y.; Ullah, A.; Khan, A.Q.; Menghwar, H.; Khan, A.H.; Ahmed, M.M.; Tabassum, M.A.; Zhu, L. Physiological and molecular mechanism of defense in cotton against Verticillium dahliae. Plant Physiol. Biochem. 2018, 125, 193-204. [CrossRef]

47. Noman, A.; Liu, Z.; Aqeel, M.; Zainab, M.; Khan, M.I.; Hussain, A.; Ashraf, M.F.; Li, X.; Weng, Y.; He, S. Basic leucine zipper domain transcription factors: The vanguards in plant immunity. Biotechnol. Lett. 2017, 39, 1779-1791. [CrossRef]

48. Shi, F.M.; Yao, L.L.; Pei, B.L.; Zhou, Q.; Li, X.L.; Li, Y.; Li, Y.Z. Cortical microtubule as a sensor and target of nitric oxide signal during the defence responses to Verticillium dahliae toxins in Arabidopsis. Plant Cell Environ. 2009, 32, 428-438. [CrossRef]

49. Mwaba, I.; Rey, M.E.C. Nitric oxide associated protein 1 is associated with chloroplast perturbation and disease symptoms in Nicotiana benthamiana infected with South African cassava mosaic virus. Virus Res. 2017, 238, 75-83. [CrossRef]

50. Wang, J.-Y.; Cai, Y.; Gou, J.-Y.; Mao, Y.-B.; Xu, Y.-H.; Jiang, W.-H.; Chen, X.-Y. VdNEP, an Elicitor from Verticillium dahliae, induces cotton plant wilting. Appl. Environ. Microbiol. 2004, 70, 4989-4995. [CrossRef]

51. Zhang, Y.-L.; Ya-Lin, Z.; Feng, Z.-L.; Feng, H.-J.; Zhao, L.-H.; Shi, Y.-Q.; Hu, X.-P.; Zhu, H. Isolation and functional analysis of the pathogenicity-related gene VdPR3 from Verticillium dahliae on cotton. Curr. Genet. 2015, 61, 555-566. [CrossRef] 
52. Hu, X.; Bai, Y.; Chen, T.; Hu, D.; Yang, J.; Chen, W.-H. An optimized method for in vitro production of Verticillium dahliae microsclerotia. Eur. J. Plant Pathol. 2013, 136, 225-229. [CrossRef]

53. Zhu, H.; Feng, Z.-L.; Li, Z.; Shi, Y.-Q.; Zhao, L.-H.; Yang, J.-R. Characterization of two fungal isolates from cotton and evaluation of their potential for biocontrol of verticillium wilt of cotton. J. Phytopathol. 2013, 161, 70-77. [CrossRef]

54. Zhang, Y.; Na, Y.; Zhao, L.; Zhu, H.; Canming, T. Transcriptome analysis reveals the defense mechanism of cotton against Verticillium dahliae in the presence of the biocontrol fungus Chaetomium globosum CEF-082. BMC Plant Biol. 2020, 20, 1-15. [CrossRef] [PubMed]

55. Tzima, A.K.; Paplomatas, E.J.; Rauyaree, P.; Ospina-Giraldo, M.D.; Kang, S. VdSNF1, the sucrose nonfermenting protein kinase gene of verticillium dahliae, is required for virulence and expression of genes involved in cell-wall degradation. Mol. Plant Microb. Interact. 2011, 24, 129-142. [CrossRef] [PubMed]

56. Zhang, X.; Feng, Z.; Zhao, L.; Liu, S.; Wei, F.; Shi, Y.; Feng, H.; Zhu, H. Succinate dehydrogenase SDH1-1 positively regulates cotton resistance to Verticillium dahliae through a salicylic acid pathway. J. Cotton Res. 2020, 3, 1-12. [CrossRef] 